This is a self-archived - parallel published version of this article in the publication archive of the University of Vaasa. It might differ from the original.

\title{
Identification of Critical Factors and Their Interrelationships to Design Agile Supply Chain: Special Focus to Oil and Gas Industries
}

Author(s): Piya, Surjan; Shamsuzzoha, Ahm; Khadem, Mohammad; Al-Hina, Nasr

Title: $\quad$ Identification of Critical Factors and Their Interrelationships to Design Agile Supply Chain: Special Focus to Oil and Gas Industries

Year: $\quad 2020$

Version: Accepted manuscript

Copyright (C)2020 Springer Nature. This is a post-peer-review, pre-copyedit version of an article published in Global Journal of Flexible Systems Management. The final authenticated version is available online at: http://dx.doi.org/10.1007/s40171-020-00247-5

Please cite the original version:

Piya, S., Shamsuzzoha, A., Khadem, M. \& Al-Hina, N. (2020). Identification of Critical Factors and Their Interrelationships to Design Agile Supply Chain: Special Focus to Oil and Gas Industries. Global Journal of Flexible Systems Management 21(3), 263-281. https://doi.org/10.1007/s40171-020-00247-5 


\title{
Identification of critical factors and their inter-relationships to design agile supply chain: special focus on oil and gas industry
}

\begin{abstract}
Purpose - This research attempted to identify the most critical factors and their inter-relationships to ensure designing agile supply chain, especially in oil and gas industry. This factors identification process is performed through developing a conceptual framework and the use of Interpretive Structural Modelling (ISM) tool.

Design/methodology/approach - This study is conducted through an extensive literature review and questionnaires survey to identify and refine the critical factors that ensure the agile supply chain in oil and gas industry. In addition, several brainstorming sessions with the experts in the field of oil and gas industries were organized with the objective to interpret the contextual interrelationships between the identified factors. The outcomes from the literature reviews, interview questions and experts' opinions were used to develop a diagraph and MICMAC analysis to know the drivers of agility in supply chain.

Findings -From this study, 34 enablers and 12 factors were identified, which are responsible to ensure agile supply chain in oil and gas industry. Out of these identified factors, top management commitment, strategic alignment, competency of management and integration of information and systems technology are found to be the critical drivers of supply chain agility. On the other hand, government regulations, transportation and logistics flexibility and production planning and control falls under the category of dependent factors.

Originality/value - The identified factors and their interrelationships can be a valuable aid to ensure and measure the agility in supply chain, especially in oil and gas industry. These identified factors and their defined consequences will help managers and concerned authorities in oil and gas industry to take better decision to improve the agility level of their supply chain.
\end{abstract}

Keywords: Agile supply chain, ISM tool, MICMAC analysis. Oil and gas industry.

\section{Introduction}

Oil and gas $(\mathrm{O} \& \mathrm{G})$ industry is considered as one of the major industry around the world, upon which many manufacturing and service industries are dependent on. This industrial segment 
occupies a substantial portion of the global economy due to its massive growth and huge investments in infrastructure (Filis et al., 2011). The O\&G industry can be categorized into three major sections as follows:

- Upstream: It covers the first stage of an oil production lifecycle activities. This stage consists of processes such as drilling, wellhead, casing, extraction, separation and storage.

- Midstream: It deals with the second stage of an oil production lifecycle. This stage consists of processes such as, setting up gas plants, production of liquefied natural gas (LNG), and establishment of necessary pipeline for oil transportation.

- Downstream: It is the last stage of the oil production activities. This stage is mainly concerned about several processes such as refinement, marketing and distribution of crude oil and related products.

In todays' business environment, $\mathrm{O} \& \mathrm{G}$ industry needs to adapt to the necessary changes as orchestrated due to the market dynamics and customer needs. One way to achieve this goal is to enhance the agility of the supply chain management (SCM) in this industrial sector (Yusuf et al., 2014). To establish such agility in supply chain network, it is essential for the O\&G companies to identify the critical factors that are responsible to ensure the agility level. This factors identification process enables the decision makers in $\mathrm{O} \& \mathrm{G}$ industry to know where they need to focus to improve the agility level of their companies.

The supply chain network in O\&G companies are typically characterized by the fact that many large companies engaged in service and technology support their operations (Yousuf et al., 2014). In addition, to achieve extended operational efficiency and cost reduction, O\&G companies are moving from in-house sourcing capabilities to outsourcing capabilities. This strategic shifting demonstrates a significant need of having close cooperation and collaboration between supply chain stakeholders (Zhou et al., 2010).

The cooperation and collaboration among supply chain stakeholders ensures agility. There are several critical factors on which such cooperation and collaboration depends on, which needs to identify by the companies. It is however, not an easy tasks to identify such factors. Several researchers have been conducted to find the agility in supply chain in many industrial segments such as fashion industry (Christopher et al. 2004; Masson et al., 2007), textiles and clothing industry (Bruce et al., 2004), automotive industry (Sanchez and Perez, 2005), mobile industry (Collin and Lorenzin, 2006), construction industry (Naim et al., 1999), etc., however, no researches 
have been found so far in the literature focusing on $O \& G$ industry. Considering such research gap in mind, this study identified three research objectives as stated below:

(1) to identify critical factors responsible to ensure agility in supply chain within $O \& G$ industry

(2) to develop a conceptual framework to support the agile supply chain in O\&G industry

(3) to demonstrate the contextual relationships between the identified factors which can be used to bring agility into the $O \& G$ industry

The remaining of the paper is organized as follows: Section 2 summarizes the relevant literature review. The research methodology is detailed in Section 3. Sections 4 and 5 discusses the main findings of this research by defining the factors affecting agility in O\&G industry and the ISM methodology respectively. Finally, the research is concluded in Section 6 along with possible future work directions.

\section{Literature review}

\subsection{Supply chain network}

The term supply chain was coined by management consultants in 1980s (Lambert and Cooper, 2000; Lamming, 1996). The concept of SCM has started to gain more interest among researchers, as well as, industrial practitioners due to its inherent benefits. SCM can be defined as the flow of resources, services, activities and information among individuals' and/or organizations (Lu, D. 2011). This implies that it is an integral part of management of all the processes across the supply chain network (Khadem et al., 2017).

Moreover, the supply chain network may be defined as a business environment, where various supply companies collaborate with each other for mutual benefits. Such collaboration enables them to support each other by sharing resources and enhancing their competencies and capabilities. Tolone (2000) and Gosling et al. (2010) emphasized on the effective integration among supply chain members and maintaining close relationships with them. At present, the goal of the researchers and practitioners is to understanding and improving the long-term relationships between the companies and their supply chain members (Scott et al. 2011).

\subsection{Importance of agility in supply chain network}


To remain competitive, manufacturing companies need to react quickly to the changing business environment. One way to respond quickly to the market changes is by achieving agility in supply chain network (Blome et al., 2013). Bottani (2010) and Eckstein et al. (2015) showed that agility leads to decrease in the product development cost, improve operational efficiency, increase customer satisfaction and improve competitive power. More to that, Gliglor et al. (2015) used empirical analysis to show that firms supply chain agility will have positive impact on firm's overall performances and customer effectiveness.

In the early 1990s, agility was considered from the point of view of internal capabilities of the companies themselves (Miles and Snow, 1992). However, in the present context, a major competitive feature of business depends on the capability of the whole supply chain members, rather than any individual member within the chain (Christopher and Towill, 2001; Ramdas and

Speakman, 2000). This reverberate that, to be efficient, company should be able to forge its link with external organizations rather than depending only on its internal capabilities. Due to this, the issue of agility within supply chain partners is garnering strong emphasis among researchers (Charles et al. 2010; Ngai et al., 2011; Malhotra and Mackelprang, 2012; Seethamraju and Sundar, 2013; Gorane and Karn, 2013; Balaji et al., 2015; Brusset, 2016). However, through survey, Yusuf et al. (2004) demonstrated that it is still not widely practiced by the industries even though agile enterprise leads to significant impact on the low cost objective.

The performance and competitive feature of whole supply chain network depends on the degree of agility that each partner within the network possesses (Lin et al. 2006). Agile paradigm plays a significant role for the survival of whole SC network during uncertain, turbulent and volatile market environment (Gunasekaran, 1999; Christopher, 2000; Mason et al. 2002, Li et al. 2008). From the above discussion, it is quite evident that agility in supply chain network is one of the prime components to achieve competitive advantage. However, to achieve such competitive edge, a major concern is to identify the dimension(s) or the way(s) by which the level of agility within the supply chain network can be amended (Sletback et al., 2010; Xia and Tang, 2011; Costantino et al., 2012).

\subsection{Dimension of supply chain agility}

Different studies used different dimensions to measure the agility level of supply chain. For example, Meade and Sarkis (1999) stated the supply chain dimensions as cooperation, enriching 
customer, mastering change and uncertainty, and leveraging the impact of people and information to measure the agility level of supply chain. Jain et al., (2008) used both hard and soft criteria such as flexibility, profitability, quality, innovativeness, pro-activity, speed of response, cost and robustness.

Tsourveloudis et al., (2002) suggested measuring the supply chain agility level by using the dimension of production, market, people and information. Each dimension is analyzed based on various factors or performance measures. Furthermore, organization can become agile by practicing the lean concept, which is focused on identification and removal of waste from the system (Katayama and Bennett, 1999; Van et al., 2001; Aitken et al., 2002; and Stratton and Warburton, 2003). It may be worth highlighting that these two terms, lean and agility, are rather complementary than mutually exclusive (Narasimhan et al. 2006). Garbie (2011) used other dimensions to measure agility. These dimensions included technology, people, production strategies and organization management. These dimensions are further divided into factors and enablers.

\section{Research methodology}

This research was conducted following several steps such as literature reviews, preparation and distribution of both off-line and on-line questionnaires, and face-to-face interviews.

At first, an extensive review of existing literatures were conducted with the objective to identify the enablers responsible to the level of agility within supply chain. From the literature review, 26 enablers of supply chain agility were identified.

Then, based on these enablers a questionnaire was prepared using a Likert scale. Initially, the questionnaire was prepared in google docs and then e-mailed it to the managers working in $\mathrm{O} \& \mathrm{G}$ companies in Oman. The return rate from the online questionnaire was not satisfactory, which was then distributed physically to the managers at 25 different O\&G companies. During distribution of the questionnaire physically, the purpose of questionnaire and the identified enablers were explained to the corresponding managers. In addition, the managers were also requested to identify any enabler, which is not in the list but they believe that it is important and affects the agility level and provide its scale point within the given Likert scale. In total, 350 questionnaires were distributed to the managers working at different levels within these 25 O\&G companies. The 
designations of the contacted managers and the business sectors of their companies are presented in Table 1. Note that the percentage in Table 1 is presented in the round figure.

\section{Table 1: Demography of selected company and respondent}

Out of 350 distributed questionnaires, 240 responses were returned from the contacted managers. However, only 194 responses were considered in this study due to incomplete information in the remaining responses. This represents the response rate of $55.4 \%$, which is quite satisfactory in comparison to Yusuf et al. (2014). From this questionnaire survey, in total 42 enablers were collected, out of which 16 enablers were outside from the distributed questionnaire but suggested by the respondents. Out of 42 collected enablers, some enablers were merged together due to similarity in meaning and some were discarded due to very low rating from the respondents ( $<2$ in a Likert scale). The research team finally consolidated a list of 34 enablers, based on which the factors and dimensions directly affecting the agility level in O\&G supply chain are identified in consultation with the experts. These enablers, factors and dimensions are discussed in the Section 4.

Finally, to understand the relationship between the identified factors, an expert meeting was organized, where ten experts holding senior positions in five different O\&G companies participated. In the meeting, experts were informed, explained and clarified about those identified

factors. Furthermore, several brainstorming sessions were organized with the experts in a pursuit of understanding the complementary effect of one factor on other i.e., how one factor helps to accomplish the other factor. Such brainstorming technique was selected due to the fact that it is considered as one of the most effective techniques available to creative problem solving (Rawlinson, 1981). The valuable information as collected from the brainstorming sessions was then utilized in the Interpretive Structural Modelling (ISM) tool with the objective to develop an ISM diagraph and to conduct the MICMAC analysis.

\section{Factors affecting agility in oil and gas industry}

SC partners in O\&G industry is constituted with the parent company and various other companies such as equipment supplier, consultancy company, etc., which are directly or indirectly connected with each other. Many factors within the supply chain network affect agility level of 
O\&G industry (Harrison et al. 1999). These factors were identified based on the literature review and expert's opinions as discussed in Section 3. A conceptual framework is presented in Table 2, which shows the dimensions, factors, enablers and their consequences/outcomes on supply chain in $\mathrm{O} \& \mathrm{G}$ industry.

\section{Table 2: Conceptual framework of supply chain agility in O\&G industry}

As shown in Table 2, the identified 34 enablers were classified into 12 factors based on the enablers' domain. Furthermore, the factors were clustered into six dimensions. The aim of this classification was to understand the contextual relationships between the factors rather than the enablers. Details of each of the twelve factors of supply chain agility are outlined as follows:

\section{Strategic alignment}

Recognizing the SC agility as an indispensable element of competitive advantage is one of the major factors to become agile. Once agility is identified as a major factor, it has to be incorporated into the strategic vision and objective of the organization. Moreover, it has to be incorporated into the SC operational strategies and strategic planning (Gorane and Kant, 2013).

\section{Top management commitment and support}

Top management commitment and support boost the implementation of supply chain strategies and drive the introduction of agility practice in O\&G industries (Ahmad et al., 2016). Providing necessary financial support and sufficient resources are the primary obligation of top management to develop successful supply chain system. Furthermore, top management commitment ensures the firm to receive necessary attention for its efficient implementation. Apart from such primary support, it is also essential to provide a behavioral or psychological support to the staff.

3. Internal collaboration within organizations

Collaborative alliance requires the culture of sharing knowledge, skills and resources within cross functions, departments and organizational units to achieve mutual benefits. Openness and teamwork within the collaborative alliance are the preconditions for successful collaboration. In the $\mathrm{O} \& \mathrm{G}$ industry, the parent company usually consists of many functional teams or departments such as maintenance, operations, quality control, HSE, etc. Lack of 
proper cooperation and coordination between the teams or departments (for example maintenance and operations departments) may lead to huge loss to the company in terms of lead-time, effort, cost, production throughput, etc. Excellence in internal cooperation and coordination between the departments leads to an overall improvement in productivity (Sangari et al., 2015).

\section{External collaboration between the SC partners}

Effective integration and synchronization among all the SC partners can reduce the delivery lead-time, eliminate surplus inventory and improve customer service (Agarwal et al., 2006). There requires strong and long-term relationships and willingness to collaborate with the suppliers, customers as well as with the competitors. In O\&G industry, strong collaborative effort is required especially at the upstream level, where different parties are involved in the exploration of oil field, drilling of oilrigs, transporting crude oil to the refinery center and so on. The performance level of supply chain will increase as collaboration between these partners increases until it reaches the tipping point beyond which the performance starts to decline (Betts et al., 2009). Therefore, the collaboration between the partners should be logical and balanced.

\section{Integration of Information and Communication Technology (ICT)}

The integration of information and communication technology (ICT) helps to share data among partners, which in effect forms a virtual SC collaboration. Electronic Data Interchange (EDI) together with the availability of Internet have facilitated the supply chain partners in the O\&G industry to act upon the same information rather than to depend on the distorted information that usually emerge out in the extended SC (Chang et al., 2013). The complex nature of work with large volume of data interchange coupled with highly collaborative work process between various supply chain partners within onshore and offshore locations demand the need of robust and special ICT in O\&G industry. In order to bring real time communication, some companies even have online groups/forums (Prater et al., 2001). Overby et al. (2006), Swafford et al. (2008) and Yang (2014) demonstrated that there exists strong relationship between the company's ICT capability and associated supply chain agility. ICT improves the ability of the company to sense market changes and, hence, change in the work environment through adequate, accurate and timely flow of information among supply chain partners (DeGroote and Maxrx, 2013). 


\section{Implementation of new/ advanced technologies}

Agility level of supply chain can be accomplished through the integration of organization, people and advanced technologies (Kidd, 1995; Ramesh and Devadasan, 2007). Advanced and state-of-the-art technology is especially needed at the upstream level of O\&G supply chain, which involves tasks like exploration, drilling and extraction of oil. Possibility of using robots in hazardous places, ability to implement new manufacturing technology, use of material handling equipment in moving and transporting materials throughout processes and latest available modifications in the system needs to be considered (Garbie, 2008). Furthermore, the use of computer-assisted technologies concerning administration, production system and planning enhances flexibly of production facilities (Agarwal et al., 2006).

\section{Management competence}

Relationship-oriented, participative leadership and delegation of work at the lower level of management hierarchy is found to play important role in agile enterprises (Sherehiy et al., 2007). The term flexibility, also an important component, is defined as the ability of the company to adapt and react to unpredicted changes in the internal and external work environment. Therefore, managers necessitate competence in change management and managing SC resources to successfully implement those changes. This also includes participation of managers in strategy formulation and planning to meet and support organizational objectives. Also, due to the nature of work and the need to work with large number of supply chain partners and stakeholders, conflict on various issues among partners and stakeholders is widely prevalent in $O \& G$ industry. Therefore, the manager in $O \& G$ industry should have special skill to resolve conflict through internal collaboration and negotiation.

\section{Employee competency}

Achievement of agility requires developing technologically competent, highly skilled, and flexible workforce. This workforce should have the capability to address repetitive as well as non-repetitive issues. In many sector of $O \& G$ industry, employee has to work under very challenging and hostile environment. Exploration and production of oil is highly demanding in terms of its need for skill, resilience both physically as well as psychologically and technical capability. Therefore, different requirements on the workforce are needed in comparison with 
traditional systems such as different skill sets with usually higher average skill levels. Employee must be able to support plans and strategies devised by top management and helps to implement the response of organization to the change in internal and external environment (Ngai et al. 2011).

\section{Organization culture}

Culture practiced in organization can greatly affects agility. The nature of work practiced in O\&G industry for the production and development of oil and gas involves extremely sophisticated, hazardous as well as capital and labor-intensive process. Therefore, the culture should support learning, experimentation, and innovation with the focus on continuous improvement through regular monitoring of environment to identify the necessary changes (Sherehiy et al., 2007). Furthermore, the enterprise has to be quick in decision-making and execution process, be able to include new ideas and creativity with continuous update and revision of strategy. Openness for sharing of information across all the SC partners is the foundation in order to be adaptive.

10. Operations planning and control

Operations planning and control involves making a plan for production and manufacturing processes inside the company. In O\&G industry, it includes material requirement planning, demand forecasting, scheduling future projects, capacity planning for present and future demand, inventory management and controlling quality issues. Proper planning and control is extremely necessary in order to eliminate or to minimize the probable risks and execute the operational process safely. The companies have recently noticed that nowadays the market is concerned more on customization and they should have a flexible manufacturing system in order to have competitive advantage (Yusuf et al., 2014). Quality control is recognized as an indispensable component to survive with competition. Improving the quality of overall supply chain process results into efficient utilization of resources, increase customer satisfaction, reduced cost and effort (Beamon and Ware, 1998).

\section{Transportation and logistics flexibility}

Zhao et al. (2001) has demonstrated that logistics capability of the supply chain network is one of the major competitive sources for the firms to survive in the globalized world. According to Swafford et al. (2006), distribution or logistics flexibility positively affects the level of agility. Movement of goods in the form of customer order and then going through 
supply, production and finally delivering back to customer in the form of product requires logistics capabilities to be robust enough to respond to constantly changing situation (Gligor and Holcomb, 2012). Transportation decision in O\&G supply chain involves modal selection such as rail, pipes, truck, air, or water (Mason et al., 2002) either at the upstream stage or at the downstream level. Sustainability, as well as, issue of tracking and tracing of transportation logistics are other important issues in O\&G supply chain.

\section{Government statutes and regulations}

New policies and regulations are external factors or constraints that influences the internal environment of business operations and therefore are sometimes beyond the control of enterprise (Hillegersberg et al., 2005). Government regulations influence the needs and preferences of the customers (Kohli and Jaworski, 1990). Moreover, it also affects the way company can function themselves. Regulations placed by government on health and safety, policy on offshore/onshore drilling practice, issues related to carbon footprint, etc. requires to continuously be reviewed by $\mathrm{O} \& \mathrm{G}$ industry in order to react to timely changes and to obtain necessary compliance. Enterprise should have a mechanism to monitor such changes and to act on it quickly.

\section{ISM Methodology}

ISM is a well-known method to translate complicated taxonomy into manageable sub-system (Sage, 1977). Warfield (1974) proposed it first time in a pursuit of identifying the interrelationship between elements associated within a system. The method uses expert's knowledge and experience to provide an ordered and directional framework for complex problems, thereby, allowing concerned authority to understand the variables involved and to observe a realistic picture of the situation for decision-making. Since the inception, the ISM method has been used for many purposes in different areas, some of which are listed in Table 3.

\section{Table 3: Application of ISM in different domains}

This research study utilizes the ISM methodology with the objective to identify contextual relationships between the identified factors of supply chain agility. The major steps involved in 
the ISM are shown in Figure 1. From Figure 1, it is evident that six steps were considered while using the ISM tool. Details of each of the step is explained below.

\section{Figure 1: Steps in using ISM}

\section{Step 1: Factor identification}

Factors that affect the level of agility have been identified and presented in Table 1. These factors are based on the extensive literature reviews and questionnaire survey with the experts' opinions.

\section{Step 2: Structural self-interaction matrix (SSIM)}

Once the factors are identified, for better understanding, it is essential to know the contextual relationship that exists between these factors. Use of ISM helps to simplify a complex system into sub-systems as a multilevel model (Gorane and Kant, 2013). Multilevel model can be considered as a statistical model of parameters that vary at more than one level (Bryk and Raudenbush, 2002). This modelling is generally used to handle clustered or grouped data. It is particularly useful and implemented for research designs where the collected study data are organized at more than one level (Fidell and Tabachnick, 2007). This modelling technique can also be used to analyze repeated measures data.

In ISM, a structural self-interaction matrix (SSIM) is developed to define contextual relationship that exists between factors. The relationship is identified through brainstorming sessions that were held multiple times to get consensus among ten experts, the result of which is as shown in Table 4. In order to express the relationships between the identified factors four symbols were used in the table namely ' $V$ ', ' $A$ ', ' $X$ ', and ' $O$ '. Details of the symbols are given as follows:

$V$ : factor $i$ will complement factor $j$

$A$ : factor $j$ will complement factor $i$

$X$ : factor $i$ and $j$ will complement each other

$O$ : no relationship between factor $i$ and $j$

\section{Table 4: Structured self-interaction matrix (SSIM)}


Initial reachability matrix (IRM) as shown in Table 5 is generated from Table 4 by substituting the alphabet with binary values 1 's and 0 's based on the following rule:

- In SSIM if the alphabet is $V$ for factor $(i, j)$, then the binary value in IRM for $(i, j)$ becomes 1 , and $(j, i)$ becomes 0 .

- In SSIM if the alphabet is $A$ for factor $(i, j)$, then the binary value in IRM for $(i, j)$ becomes 0 , and $(j, i)$ becomes 1 .

- In SSIM if the alphabet is $X$ for factor $(i, j)$, then the binary value in IRM for $(i, j)$ becomes 1 , and $(j, i)$ also becomes 1 .

- In SSIM if the alphabet is $O$ for factor $(i, j)$, then the binary value in IRM for both $(i, j)$ and $(j, i)$ becomes 0 .

\section{Table 5: Initial reachability matrix (IRM)}

Once the IRM is developed, it is necessary to check for internal consistency between the relationships. Such internal consistency can be checked using the concept of transitivity which states that if $\mathrm{A}$ is related to $\mathrm{B}$ and $\mathrm{B}$ is related to $\mathrm{C}$, then $\mathrm{A}$ must be related to $\mathrm{C}$. In using ISM, transitivity of contextual relation is a basic assumption made. Table 6 shows the final RM after using the concept of transitivity. $1^{*}$ in Table 6 represents change in the relationship between variables due to transitivity.

\section{Table 6: Final reachability matrix}

\section{Step 4: Level partition}

From the final RM, reachability set and antecedent set are derived for each variable. The reachability set consists of factor $(i)$ itself and others factors $(j)$, which it may help to accomplish. On the other hand, the antecedent set consists of factor $(i)$ itself and the other factors $(j)$, which may help in its accomplishment. Thereafter, the common factors of these two sets help in obtaining interaction set. The factors that have the same reachability and intersection sets in the first iteration will be clustered as level I. The top-level factor in the hierarchy i.e., level I will not help to accomplish any other factors above its level. Once the top-level factor is identified, it is eliminated from the completely remaining sets and same procedure is repeated to find the second level factors in the next iteration and continue doing so until the last factor remains in the sets. The outcomes from seven iterations are shown in Table 7. 


\section{Table 7: Levels of factors that affect agility in O\&G industry}

Step 5: Develop conical matrix

Table 8 shows a conical matrix, which is based on the final RM and the result of level partitioning. The matrix is the result of clustering factors that are at the same level. Conical matrix makes it easy to develop the ISM diagraph.

\section{Table 8: Conical matrix with factor ranking}

\section{Step 6: ISM Diagraph}

Based on the conical matrix as displayed in Table 8 and after removing indirect links a diagraph is generated, which is as shown in Figure 2. The relationship between factors $i$ and $j$ is indicated by an arc directed from $i$ to $j$ in the graph. The result from the ISM diagraph shows that the system has six levels of factors. The factors such as government statute \& regulation, operations planning \& control and transportation \& logistics flexibility have the highest levels i.e. levels I and II, which means that they have the highest level of dependency. These factors are highly dependent on other factors that affect the agility level of supply chain in O\&G industry. On the other hand, the factors such as top management support and strategic alignment falls under the lowest level i.e. level VI, which means that these factors have the highest driving power. They drive all other factors that affect agility level (Chidambaranathan et al. 2009). Other factors lay within these two levels. It can also be noticed from Figure 2 that in the level consisting of two factors, there are two-way relationships between each other. Even though factor 6 lays at the same level as factors 3 and 4, factor 6 does not have any inter-relationship with them. From the analysis, it can be concluded that the most important factor to establish agility in O\&G supply chain is the top management support and strategic alignment.

Figure 2: ISM diagraph for supply chain agility

\subsection{MICMAC analysis}


MICMAC analysis can be used to analyze the identified factors based on their driving power and dependency towards the supply chain agility (Sharma and Gupta, 1995). The required driving power and dependency of the factors are obtained from Table 8, which are achieved by summing up the binary values towards the row and column, respectively. The driving power and dependency helps to categorize the identified factors into rank; e.g. factor 3 has $5^{\text {th }}$ rank in driving power and $3^{\text {rd }}$ rank in dependence. Also, depending on the level of driving power and dependency, the factors can be clustered into four different quadrants as shown in Figure 3.

\section{Figure 3: MICMAC analysis}

First quadrant: This quadrant is known as an autonomous quadrant due to the fact that the factors in this quadrant have less driving power and less dependency. These factors are usually disconnected from the system. Factor such as Government statute and regulations (12) falls under this quadrant.

Second quadrant: Factors that fall under this quadrant are known as dependent factors, which have low driving power but high dependency. From the present study, it is identified that six factors fall under this quadrant. These factors are: Internal collaboration (3), External collaboration between supply chain partners (4), Implementation of advanced technology (6), Employee competency (8), Transportation and logistics flexibility (11) and Operations planning and control (10). These factors are heavily affected by the factors that fall under fourth quadrant.

Third quadrant: Factors with high driving power and high dependency falls under this quadrant. This quadrant is known as linkage, meaning that any action on the factors within this quadrant will have knock on effect on others. In the current study, there is no factor that falls under this quadrant. Fourth quadrant: This quadrant consists of the factors that have strong driving power but weak dependency. In this study, five factors fall under this category, which are Strategic alignment (1), Top management commitment and support (2), Integration of information systems technology (5), Management competency (7) and Organization culture (9). All these factors drive other factors to accomplish agility within $O \& G$ supply chain.

\section{Conclusions and future works}


Supply chain agility is a critical issue in the prosperity of any industrial sectors, especially in oil and gas industry. It is important to bring agility in supply chain in oil and gas industry in order to reduce lead time and increase productivity. In order to ensure agility in supply chain stakeholders, it is necessary to identify the associated factors responsible for the agility. The main objectives of this research study were therefore to identify those factors and display their interrelationships. In order to full such objectives, this study was carried out to identify these factors through an extensive literature review and experts' opinions. A set of questionnaires was prepared based on these factors and distributed among the supply chain experts in oil and gas industry to find out the relationships among these factors.

Based on the collected factors, a conceptual framework of supply chain agility in oil and gas industry was developed. This framework categorizes the collected factors depending on the dimensions, factors, enablers and consequences/outcomes. In addition, the ISM tool was used to identify the contextual relationship between these identified factors. The result from the ISM was presented in the form of a diagraph for supply chain agility, as well as, MICMAC analysis. This diagraph visualizes the various levels of the factors depending on their importance. From the diagraph it is noticed that top management support, strategic alignment, organizational culture and management competency are the most important factors and categorize in top two levels (levels 5 and 6). On the other hand, factors such as government regulation, operations planning and control and transportation and logistics flexibility are the low importance factors to ensure supply chain agility in oil and gas industry.

Although, this study was focused on identifying the factors and enablers to bring agility in O\&G industry, it can also be used in other industrial segments/companies as well. The applicability of these factors in $O \& G$ industry is demonstrated within the scope of this study. From such analysis, the managers in $\mathrm{O} \& \mathrm{G}$ industry would be able to monitor continuously their supply chain activities and enable them to take necessary actions/measures to control their supply chain processes effectively and efficiently. The result of this study can be used as a guideline for O\&G companies to execute their supply chain towards agility.

Based on the conceptual framework as developed within the scope of this research, future research can be extended to formulate a mathematical model that can be used to measure the agility level of O\&G industry supply chain. This may also be helpful for any other companies and their 
supply chain partners to identify the factors on which the companies need to focus more to become agile. Moreover, future work can also be concentrated to study the supply chain agility level from one industrial segment to another one with the objective to make a comparative study or benchmarking.

\section{References}

- Agarwal, A., Shankar, R., \& Tiwari, M. K. (2006). Modeling the metrics of lean, agile and leagile supply chain: An ANP-based approach. European Journal of Operational Research, 173(1), 211-225.

- Ahmad, W. N. K. W., Rezaei, J., Tavasszy, L. A., \& De Brito, M. P. (2016). Commitment to and preparedness for sustainable supply chain management in the oil and gas industry. Journal of environmental management, 180, 202-213.

- Aitken, J., Christopher, M., \& Towill, D. (2002). Understanding, implementing and exploiting agility and leanness. International Journal of Logistics: Research and Applications, 5(1), 59-74.

- Alzebdeh, K., Bashir, H. A., \& Alsiyabi, S.K. (2015). Applying Interpretive Structural Modeling to Cost Overruns in Construction Projects in the Sultanate of Oman, The Journal of Engineering Research, 12 (1), 53-68.

- Bal, J., Wilding, R., \& Gundry, J. (1999). Virtual teaming in the agile supply chain. International Journal of Logistics Management, 10(2), 71-82.

- Balaji, M., Velmurugan, V., \& Subashree, C. (2015). OriginalTADS: An assessment methodology for agile supply chains. Journal of Applied Research and Technology, 13(5).

- Beamon, B. M., \& Ware, T. M. (1998). A process quality model for the analysis, improvement and control of supply chain systems. Logistics Information Management, 11(2), 105-113.

- Betts, T., \& Tadisina, S. K. (2009). Supply chain agility, collaboration, and performance: how do they relate. In Proceedings of Annual Conference of the Production and Operations Management Society, Orlando, USA.

- Blome, C., Schoenherr, T., \& Rexhausen, D. (2013). Antecedents and enablers of supply chain agility and its effect on performance: a dynamic capabilities perspective. International Journal of Production Research, 51(4), 1295-1318.

- Bolanos, R., Fontela, E., Nenclares, A., \& Paster, P. (2005). Using interpretive structural modeling in strategic decision making groups. Management Decision, 43(6), 877-895. 
- Bottani, E. (2010). Profile and enablers of agile companies: An empirical investigation. International Journal of Production Economics, 125(2), 251-261.

- Bruce, M., Daly, L. \& Towers, N. (2004). Lean or agile: A solution for supply chain management in the textiles and clothing industry?. International Journal of Operations \& Production Management, 24(2), 151-170.

- Brusset, X. (2016). Does supply chain visibility enhance agility? International Journal of Production Economics, 171, 46-59.

- Bryk, S. W. \& Raudenbush, A.S. (2002). Hierarchical linear models: applications and data analysis methods (2. ed., [3. Dr.] ed.). Thousand Oaks, CA [u.a.]: Sage Publications.

- Chang, A. Y., Hu, K. J., \& Hong, Y. L. (2013). An ISM-ANP approach to identifying key agile factors in launching a new product into mass production. International Journal of Production Research, 51(2), 582-597.

- Charles, A., Lauras, M., \& Van Wassenhove, L. (2010). A model to define and assess the agility of supply chains: building on humanitarian experience. International Journal of Physical Distribution \& Logistics Management, 40(8/9), 722-741.

- Chidambaranathan, S., Muralidharan, C., \& Deshmukh, S. G. (2009). Analyzing the interaction of critical factors of supplier development using Interpretive Structural Modeling — an empirical study. The International Journal of Advanced Manufacturing Technology, 43(11-12), 10811093.

- Christopher, M. (2000). The agile supply chain: competing in volatile markets. Industrial marketing management, 29(1), 37-44.

- Christopher, M., \& Towill, D. (2001). An integrated model for the design of agile supply chains. International Journal of Physical Distribution \& Logistics Management, 31(4), 235-246.

- Christopher, M., Lowson, R. \& Peck, H. (2004). Creating agile supply chains in the fashion industry. International Journal of Retail \& Distribution Management, 32(8), 367-376.

- Collin, J. \& Lorenzin, D. (2006). Plan for supply chain agility at Nokia: Lessons from the mobile infrastructure industry. International Journal of Physical Distribution \& Logistics Management, 36(6), 418-430.

- Costantino, N., Dotoli, M., Falagario, M., Fanti, M. P., \& Mangini, A. M. (2012). A model for supply management of agile manufacturing supply chains. International Journal of Production Economics, 135(1), 451-457. 
- DeGroote, S. E., \& Marx, T. G. (2013). The impact of IT on supply chain agility and firm performance: an empirical investigation. International Journal of Information Management, 33(6), 909-916.

- Dubey, R., Gunasekaran, A., Wamba, S. F., \& Bag, S. (2015). Building Theory of Green Supply Chain Management using Total Interpretive Structural Modeling (TISM). IFAC-PapersOnLine, 48(3), 1688-1694.

- Eckstein, D., Goellner, M., Blome, C., \& Henke, M. (2015). The performance impact of supply chain agility and supply chain adaptability: the moderating effect of product complexity. International Journal of Production Research, 53(10), 3028-3046.

- Fidell, B.G., Tabachnick, L.S. (2007). Using multivariate statistics (5th ed.). Boston ; Montreal: Pearson/A \& B.

- Filis, G., Degiannakis, S. \& Floros, C. (2011). Dynamic correlation between stock market and oil prices: The case of oil-importing and oil-exporting countries. International Review of Financial Analysis, 20(3), 152-164.

- Garbie, I. H., Parsaei, H. R., \& Leep, H. R. (2008). A novel approach for measuring agility in manufacturing firms. International Journal of Computer Applications in Technology, 32(2), 95103.

- Garbie, I. H. (2011). Implementation of agility concepts into oil industry. Journal of Service Science and Management, 4(02), 203.

- Gligor, D. M., \& Holcomb, M. C. (2012). Understanding the role of logistics capabilities in achieving supply chain agility: a systematic literature review. Supply Chain Management: An International Journal, 17(4), 438-453.

- Gligor, D. M., Esmark, C. L., \& Holcomb, M. C. (2015). Performance outcomes of supply chain agility: when should you be agile?. Journal of Operations Management, 33, 71-82.

- Gosling, J., Purvis, L., \& Naim, M. M. (2010). Supply chain flexibility as a determinant of supplier selection. International Journal of Production Economics, 128(1), 11-21.

- Gorane, S. J., \& Kant, R. (2013). Modeling the SCM enablers: an integrated ISM-fuzzy MICMAC approach. Asia Pacific Journal of Marketing and Logistics, 25(2), 263-286.

- Govindan, K., Palaniappan, M., Zhu, Q., \& Kannan, D. (2012). Analysis of third party reverse logistics provider using interpretive structural modeling. International Journal of Production Economics, 140(1), 204-211. 
- Gunasekaran, A. (1999). Agile manufacturing: a framework for research and development. International journal of production economics, 62(1), 87-105.

- Harrison, A., Christopher, M., \& Van Hoek, R. (1999). Creating the Agile Supply Chain. London: Institute of Logistics \& Transport.

- Hillegersberg, J. (2005). Business agility requirement in financial services. Journal of Rotterdam, School of Management, Erasmus University Rotterdam.

- Hussain, M., Awasthi, A., \& Tiwari, M. K. (2016). Interpretive structural modeling-analytic network process integrated framework for evaluating sustainable supply chain management alternatives. Applied Mathematical Modelling, 40(5), 3671-3687.

- Jain, V., Benyoucef, L., \& Deshmukh, S. G. (2008). A new approach for evaluating agility in supply chains using fuzzy association rules mining. Engineering Applications of Artificial Intelligence, 21(3), 367-385.

- Katayama, H., \& Bennett, D. (1999). Agility, adaptability and leanness: A comparison of concepts and a study of practice. International Journal of Production Economics, 60-61, 43-51.

- Khadem, M., Shamsuzzoha, A., \& Piya, S. (2017). Optimization Modeling of a Poultry Industry Supply Chain Network. International Journal of Supply Chain Management, 6(2), 27-32.

- Kidd, P. T. (1995). Agile manufacturing: forging new frontiers. Addison-Wesley Longman Publishing Co., Inc.

- Kohli, A. K., \& Jaworski, B. J. (1990). Market orientation: the construct, research propositions, and managerial implications. The Journal of Marketing, 1-18.

- Lambert, D. M., \& Cooper, M. C. (2000). Issues in supply chain management. Industrial marketing management, 29(1), 65-83.

- Lamming, R. (1996). Squaring lean supply with supply chain management. International Journal of Operations \& Production Management, 16(2), 183-196.

- Li, X., Chung, C., Goldsby, T. J., \& Holsapple, C. W. (2008). A unified model of supply chain agility: the work-design perspective. The International Journal of Logistics Management, 19(3), 408-435.

- Lin, C. T., Chiu, H., \& Chu, P. Y. (2006). Agility index in the supply chain. International Journal of Production Economics, 100(2), 285-299. 
- Lin, Y. T., Lin, C. L., Yu, H. C., \& Tzeng, G. H. (2011). Utilization of interpretive structural modelling method in the analysis of interrelationship of vendor performance factors. International Journal of Business Performance Management, 12(3), 260-275.

- Lu, D. (2011). Fundamentals of supply chain management. Bookboon.

- Malhotra, M. K., \& Mackelprang, A. W. (2012). Are internal manufacturing and external supply chain flexibilities complementary capabilities? Journal of Operations Management, 30(3), 180200.

- Mandal, A., \& Deshmukh, S. G. (1994). Vendor selection using Interpretive Structural Modeling (ISM). International Journal of Operations and Production Management, 14(6), 52-59.

- Manoharan, T. R., Muralidharan, C., \& Deshmukh, S. G. (2010). Analyzing the interaction of performance appraisal factors using interpretive structural modeling. Performance Improvement, 49(6), 25-35.

- Mason, S. J., Cole, M. H., Ulrey, B. T., \& Yan, L. (2002). Improving electronics manufacturing supply chain agility through outsourcing. International Journal of Physical Distribution and Logistics Management, 32(7), 610-620.

- Masson, R., Iosif, L., MacKerron, G. \& Fernie, J. (2007). Managing complexity in agile global fashion industry supply chains. The International Journal of Logistics Management, 18(2), 238254.

- Meade, L. M., \& Sarkis, J. (1999). Analyzing organizational project alternatives for agile manufacturing processes: an analytical network approach. International Journal of Production Research, 37(2), 241-261.

- Miles, R. E., \& Snow, C. C. (1992). Causes of failure in network organizations. California management review, 34(4), 53-72.

- Mitra Debnath, R., \& Shankar, R. (2012). Improving service quality in technical education: use of interpretive structural modeling. Quality Assurance in Education, 20(4), 387-407.

- Naim, M., Naylor, J. \& Barlow, J. (1999). Developing lean and agile supply chains in the UK housebuilding industry. Proceedings IGLC-7, 26-28 July 1999, University of California, Berkeley, CA, USA, 159-170.

- Narasimhan, R., Swink, M., \& Kim, S. W. (2006). Disentangling leanness and agility: an empirical investigation. Journal of operations management, 24(5), 440-457. 
- Ngai, E. W., Chau, D. C., \& Chan, T. L. A. (2011). Information technology, operational, and management competencies for supply chain agility: Findings from case studies. The Journal of Strategic Information Systems, 20(3), 232-249.

- Overby, E., Bharadwaj, A., \& Sambamurthy, V. (2006). Enterprise agility and the enabling role of information technology. European Journal of Information Systems, 15(2), 120-131.

- Poloie, K., Fazli, S., Alvandi, M., \& Hasanlo, S. (2012). A framework for measuring the supply chain's agility of mass construction industry in Iran. Management Science Letters, 2(7), 23172334.

- Prater, E., Biehl, M., \& Smith, M. A. (2001). International supply chain agility-Tradeoffs between flexibility and uncertainty. International journal of operations and production management, 21(5/6), 823-839.

- Rawlinson, J. G. (1981). Creative thinking and brainstorming. Farnborough, Hants: Gower.

- Ramdas, K., \& Spekman, R. E. (2000). Chain or shackles: understanding what drives supplychain performance. Interfaces, 30(4), 3-21.

- Ramesh, G., \& Devadasan, S. R. (2007). Literature review on the agile manufacturing criteria. Journal of Manufacturing Technology Management, 18(2), 182-201.

- Ravi, V., \& Shankar, R. (2005). Analysis of interactions among the barriers of reverse logistics. Technological Forecasting and Social Changes, 72 (8), 1011-1029

- Sage, A. P. (1977). Interpretive structural modeling: Methodology for largescale systems. New York, NY: McGraw-Hill.

- Sagheer, S., Yadav, S. S., \& Deshmukh, S. G. (2009). An application of interpretative structural modeling of the compliance to food standards. International Journal of Productivity and Performance Management, 58(2), 136-159.

- Sánchez, A.M. \& Pérez, M.P. (2005). Supply chain flexibility and firm performance: A conceptual model and empirical study in the automotive industry. International Journal of Operations \& Production Management, 25(7), 681-700.

- Sangari, M. S., Razmi, J., \& Zolfaghari, S. (2015). Developing a practical evaluation framework for identifying critical factors to achieve supply chain agility. Measurement, 62, 205-214.

- Scott, C., Lundgren, H., \& Thompson, P. (2011). Guide to supply chain management. Springer Science \& Business Media. 
- Seethamraju, R., \& Sundar, D. K. (2013). Influence of ERP systems on business process agility. IIMB Management Review, 25(3), 137-149.

- Sharma, R., \& Garg, S. (2010). Interpretive structural modelling of enablers for improving the performance of automobile service centre. International Journal of Services Operations and Informatics, 5(4), 351-372.

- Sharma, H. D., \& Gupta, A. D. (1995). The objectives of waste management in India: a futures inquiry. Technological Forecasting and Social Change, 48(3), 285-309.

- Sherehiy, B., Karwowski, W., \& Layer, J. K. (2007). A review of enterprise agility: Concepts, frameworks, and attributes. International Journal of industrial ergonomics, 37(5), 445-460.

- Singh, M. D., \& Kant, R. (2008). Knowledge management barriers: An interpretive structural modeling approach. International Journal of Management Science and Engineering Management, 3(2), 141-150.

- Singh, M. D., Shankar, R., Narain, R., \& Agarwal, A. (2003). Knowledge management in engineering industries - an interpretive structural modeling. Journal of Advances in Management Research, 1(1), 27-39.

- Sletbakk Ramstad, L., Halvorsen, K., \& Wahl, A. M. (2010, January). Improved Coordination with Integrated Planning: Organisational Capabilities. In SPE Intelligent Energy Conference and Exhibition. Society of Petroleum Engineers.

- Swafford, P. M., Ghosh, S., \& Murthy, N. (2006). The antecedents of supply chain agility of a firm: scale development and model testing. Journal of Operations Management, 24(2), 170-188.

- Swafford, P. M., Ghosh, S., \& Murthy, N. (2008). Achieving supply chain agility through IT integration and flexibility. International Journal of Production Economics, 116(2), 288-297.

- Stratton, R., \& Warburton, R. D. H. (2003). The strategic integration of agile and lean supply. International Journal of Production Economics, 85, 183-198.

- Talib, F., Rahman, Z., \& Qureshi, M. N. (2011). Analysis of interaction among the barriers to total quality management implementation using interpretive structural modeling approach. Benchmarking: An International Journal, 18(4), 563-587.

- Thakkar, J., Deshmukh, S. G., Gupta, A. D., \& Shankar, R. (2006). Development of a balanced scorecard: an integrated approach of interpretive structural modeling (ISM) and analytic network process (ANP). International Journal of Productivity and Performance Management, 56(1), 2559. 
- Thakkar, J., Kanda, A., \& Deshmukh, S. G. (2007). Evaluation of buyer-supplier relationships using an integrated mathematical approach of interpretive structural modeling (ISM) and graph theoretic matrix: the case study of Indian automotive SMEs. Journal of Manufacturing Technology Management, 19(1), 92-124.

- Tolone, W. J. (2000). Virtual situation rooms: connecting people across enterprises for supplychain agility. Computer-Aided Design, 32(2), 109-117.

- Tsourveloudis, N. C., \& Valavanis, K. P. (2002). On the measurement of enterprise agility. Journal of Intelligent and Robotic Systems, 33(3), 329-342.

- Van Hoek, R. I., Harrison, A., \& Christopher, M. (2001). Measuring agile capabilities in the supply chain. International Journal of Operations and Production Management, 21(1/2), $126-148$.

- Warfield, J. N. (1974). Toward interpretation of complex structural models. IEEE Transactions on Systems, Man, and Cybernetics, (5, 405-417.

- Wu, W. S., Yang, C. F., Chang, J. C., Château, P. A., \& Chang, Y. C. (2015). Risk assessment by integrating interpretive structural modeling and Bayesian network, case of offshore pipeline project. Reliability Engineering \& System Safety, 142, 515-524.

- Xia, Y., \& Li-Ping Tang, T. (2011). Sustainability in supply chain management: suggestions for the auto industry. Management Decision, 49(4), 495-512.

- Yang, J. (2014). Supply chain agility: Securing performance for Chinese manufacturers. International Journal of Production Economics, 150, 104-113.

- Yusuf, Y. Y., Gunasekaran, A., Adeleye, E. O., \& Sivayoganathan, K. (2004). Agile supply chain capabilities: Determinants of competitive objectives. European Journal of Operational Research, 159(2), 379-392.

- Yusuf, Y. Y., Gunasekaran, A., Musa, A., Dauda, M., El-Berishy, N. M., \& Cang, S. (2014). A relational study of supply chain agility, competitiveness and business performance in the oil and gas industry. International Journal of Production Economics, 147, 531-543.

- Yusuf, Y. Y., Musa, A., Dauda, M., El-Berishy, N., Kovvuri, D., \& Abubakar, T. (2014). A study of the diffusion of agility and cluster competitiveness in the oil and gas supply chains. International Journal of Production Economics, 147, 498-513. 
- Zhang, C., Sun, L., Wen, F., Lin, Z., Ledwich, G., \& Xue, Y. (2015). An interpretative structural modeling based network reconfiguration strategy for power systems. International Journal of Electrical Power \& Energy Systems, 65, 83-93.

- Zhao, M., Dröge, C., \& Stank, T. P. (2001). The effects of logistics capabilities on firm performance: customer-focused versus information-focused capabilities. Journal of Business Logistics, 22(2), 91-107.

Zhou, Y. C., Wang, X. N., Liu, X. P., Xue, L., Liang, S., \& Sun, C. H. (2010, July). Enabling integrated information framework as cloud services for chemical and petroleum industry. In 2010 6th World Congress on Services (pp. 1-7).

Table 1: Demography of selected company and respondent

Business sector of company where questionnaire was distributed

- Production and exploration: $26 \%$

- Logistics and transportation supplier:6\%

- Engineering service: $18 \%$

- Consultancy:16\%

- Equipment Supplier: 10\%

- Others: $24 \%$

Designation of people communicated

- Supply chain manager: $25 \%$

- Quality control manager: 6\%

- Production manager: $18 \%$

- Purchasing manager: $17 \%$

- Human resource manager: 4\%

- CEO and MD: $11 \%$

- Others: $14 \%$

Experience of people in their job (in years)

- 3 to $5: 24 \%$

- 6 to $10: 39 \%$

- 11 to $15: 17 \%$

- 16 to $20: 12 \%$

- Above 20:8\%

Company establishment (in years)

- 5 to $10: 14 \%$

- 11 to $15: 22 \%$

- 16 to $20: 41 \%$

- 21 to $25: 9 \%$ 
Table 2: Conceptual framework of supply chain agility in O\&G industry

\begin{tabular}{|c|c|c|c|}
\hline Dimension & Factor & Enabler & Consequence/ outcome \\
\hline \multirow{2}{*}{$\begin{array}{l}\text { Efficient } \\
\text { SCM } \\
\text { strategy }\end{array}$} & $\begin{array}{l}\text { 1. Strategic } \\
\text { alignment }\end{array}$ & $\begin{array}{l}\text { 1.1 Perceiving SC agility as a } \\
\text { source of competitive } \\
\text { advantage. } \\
1.2 \text { Adding agility into } \\
\text { strategic vision and } \\
\text { objectives of SC. }\end{array}$ & $\begin{array}{l}\text { - Increase relational } \\
\text { behavior } \\
\text { - Decrease conflicts } \\
\text { - Increase stakeholders } \\
\text { satisfaction }\end{array}$ \\
\hline & $\begin{array}{l}\text { 2. Top } \\
\text { management } \\
\text { commitment } \\
\text { and support }\end{array}$ & $\begin{array}{l}\text { 2.1 Ensuring high priority for } \\
\text { SC agility implementation } \\
\text { within organization. } \\
2.2 \text { Guaranteeing required } \\
\text { technical, human, financial } \\
\text { resources and attention. }\end{array}$ & $\begin{array}{l}\text { - Build a successful } \\
\text { system and create an } \\
\text { agile supporting culture } \\
\text { through clear } \\
\text { organizational } \\
\text { objectives, motivation } \\
\text { and involvement } \\
\end{array}$ \\
\hline \multirow[t]{2}{*}{$\begin{array}{l}\text { Organization } \\
\text { al } \\
\text { collaboration }\end{array}$} & $\begin{array}{l}\text { 3. Internal } \\
\text { collaboration } \\
\text { within } \\
\text { organization }\end{array}$ & $\begin{array}{l}\text { 3.1 Integration within the } \\
\text { functions and departments. } \\
3.2 \text { Collaborative and } \\
\text { cooperative work } \\
\text { environment between } \\
\text { organizational units. } \\
3.3 \text { Trust, support, teamwork } \\
\text { and openness within the } \\
\text { organization. }\end{array}$ & $\begin{array}{l}\text { - Improve cross- } \\
\text { functional collaboration } \\
\text { - Increase efficiency } \\
\text { through resource sharing } \\
\text { - Create cooperative work } \\
\text { environment }\end{array}$ \\
\hline & $\begin{array}{l}\text { 4. External } \\
\text { collaboration } \\
\text { between SC } \\
\text { partners }\end{array}$ & $\begin{array}{l}\text { 4.1 Long-term and effective } \\
\text { collaboration between all SC } \\
\text { partners. } \\
4.2 \text { Co-operation with } \\
\text { competitors. }\end{array}$ & $\begin{array}{l}\text { - Cost reduction through } \\
\text { operational flexibility } \\
\text { - Building trust through } \\
\text { sharing competencies }\end{array}$ \\
\hline
\end{tabular}




\begin{tabular}{|c|c|c|c|}
\hline & & $\begin{array}{lcc}4.3 \quad \text { Leveraging } & \text { core } \\
\text { resources } & \text { with other } \\
\text { companies operating as a } & \text { as } \\
\text { network. } & & \\
\text { 4.4 Trust between partners. }\end{array}$ & \\
\hline \multirow[t]{2}{*}{$\begin{array}{l}\text { Infrastructure } \\
\text { and } \\
\text { technology }\end{array}$} & $\begin{array}{l}\text { 5. Integration of } \\
\text { information } \\
\text { systems } \\
\text { technology }\end{array}$ & $\begin{array}{l}\text { 5.1 Integration of ICT to } \\
\text { facilitate real time } \\
\text { information flow. } \\
5.2 \text { Integration of IT into } \\
\text { processes and products. }\end{array}$ & $\begin{array}{l}\text { - Reduce product } \\
\text { development lead-time } \\
\text { - Reduce time-to-market } \\
\text { and deliver product } \\
\text { - Enhance flexibility of } \\
\text { the production facilities } \\
\text { - Improve control over } \\
\text { production processes }\end{array}$ \\
\hline & $\begin{array}{l}6 . \\
\text { Implementation } \\
\text { of advanced/ } \\
\text { new technology }\end{array}$ & $\begin{array}{l}6.1 \text { Use of state-of-the art } \\
\text { technology especially at the } \\
\text { upstream level. } \\
6.2 \text { Implementation of } \\
\text { computer-assisted } \\
\text { technologies for design, } \\
\text { administration and } \\
\text { production planning. }\end{array}$ & $\begin{array}{l}\text { - Reduce exploration time } \\
\text { and effort } \\
\text { - Improve operational } \\
\text { efficiency through } \\
\text { coordination between } \\
\text { designing and planning }\end{array}$ \\
\hline \multirow{3}{*}{$\begin{array}{l}\text { Human } \\
\text { resources and } \\
\text { company } \\
\text { culture }\end{array}$} & $\begin{array}{l}\text { 7. Management } \\
\text { competence }\end{array}$ & $\begin{array}{l}\text { 7.1 Competence in change } \\
\text { management, conflict } \\
\text { resolution and managing SC } \\
\text { resources. } \\
\text { 7.2 Participating in strategy } \\
\text { formulation and planning. } \\
\text { 7.3 Leadership quality. }\end{array}$ & $\begin{array}{l}\text { - Improve the ability to } \\
\text { meet organizational } \\
\text { objectives } \\
\text { - Administer available } \\
\text { resources efficiently } \\
\text { - Maintain high level of } \\
\text { employee performance } \\
\text { and professionalism }\end{array}$ \\
\hline & $\begin{array}{l}\text { 8. Competence } \\
\text { of employee }\end{array}$ & $\begin{array}{l}\text { 8.1 Level of knowledge and } \\
\text { creativity. } \\
8.2 \text { Educational background } \\
\text { and training. } \\
8.3 \text { Work experience and } \\
\text { technical competency. } \\
8.4 \text { Adaptability to change. }\end{array}$ & $\begin{array}{l}\text { - Enhance the ability to } \\
\text { support the plan and } \\
\text { strategy devised by top } \\
\text { management } \\
\text { - Improve the ability to } \\
\text { quickly respond to } \\
\text { internal and external } \\
\text { business changes }\end{array}$ \\
\hline & $\begin{array}{l}9 . \\
\text { Organizational } \\
\text { culture }\end{array}$ & $\begin{array}{l}\text { 9.1 Encourage innovation. } \\
\text { 9.2 Rapid decision making. } \\
\text { 9.3 Employee participation in } \\
\text { decision making. } \\
\text { 9.4 Adaptive culture based on } \\
\text { learning and change. }\end{array}$ & $\begin{array}{l}\text { - Improve teamwork and } \\
\text { trust among employees } \\
\text { - Enhance cooperation } \\
\text { through knowledge } \\
\text { sharing }\end{array}$ \\
\hline
\end{tabular}




\begin{tabular}{|c|c|c|c|}
\hline & & $\begin{array}{l}\text { 9.5 Openness for } \begin{array}{r}\text { sharing } \\
\text { information }\end{array} \\
\text { organization. }\end{array}$ & $\begin{array}{l}\text { - Augment the ability to } \\
\text { adapt changes in } \\
\text { business quickly } \\
\text { - Increase employee } \\
\text { involvement, } \\
\text { empowerment and } \\
\text { motivation } \\
\text { - Institunialize } \\
\text { transparency of } \\
\text { information across } \\
\text { supply chain }\end{array}$ \\
\hline \multirow[t]{2}{*}{$\begin{array}{l}\text { Operational } \\
\text { efficiency } \\
\text { and } \\
\text { effectiveness }\end{array}$} & $\begin{array}{l}\text { 10. Operations } \\
\text { planning and } \\
\text { control }\end{array}$ & $\begin{array}{l}\text { 10.1 Availability of stock/ } \\
\text { appropriate level of } \\
\text { inventory. } \\
\text { 10.2 Flexible manufacturing } \\
\text { system. } \\
10.3 \text { Rigid quality control } \\
\text { program. }\end{array}$ & $\begin{array}{l}\text { - Increase service level, } \\
\text { system reliability and } \\
\text { productivity } \\
\text { - Prevent unplanned } \\
\text { events } \\
\text { - Minimize risk and hit } \\
\text { production targets }\end{array}$ \\
\hline & $\begin{array}{l}11 . \\
\text { Transportation } \\
\text { and logistics } \\
\text { flexibility }\end{array}$ & $\begin{array}{l}11.1 \text { Efficient and flexible } \\
\text { means of transportation and } \\
\text { logistics system. } \\
11.2 \text { Traceability in the } \\
\text { transportation and logistics } \\
\text { chain. }\end{array}$ & $\begin{array}{l}\text { - Reduce logistics costs } \\
\text { - Increase transportation } \\
\text { safety } \\
\text { - Improve coordination } \\
\text { between production and } \\
\text { logistic units }\end{array}$ \\
\hline $\begin{array}{l}\text { Guidelines } \\
\text { and } \\
\text { legislation }\end{array}$ & $\begin{array}{l}\text { 12. Ability to } \\
\text { respond to } \\
\text { government } \\
\text { statute and } \\
\text { regulations }\end{array}$ & $\begin{array}{l}\text { 12.1 Public information } \\
\text { departments to assist in } \\
\text { providing information and } \\
\text { obtaining compliance. } \\
12.2 \text { Knowledge networks } \\
\text { and institutional mechanisms } \\
\text { to support cross-boundary } \\
\text { thinking and problem-solving } \\
\text { related to new policies, } \\
\text { regulations and restrictions. }\end{array}$ & $\begin{array}{l}\text { - Ensure compliance with } \\
\text { statutes and regulations } \\
\text { - Increase ability to adapt } \\
\text { to external constraints } \\
\text { quickly }\end{array}$ \\
\hline
\end{tabular}

Table 3: Application of ISM in different domains

\begin{tabular}{|l|l|}
\hline \multicolumn{1}{|c|}{ Paper } & \multicolumn{1}{c|}{ Area of application/ contribution } \\
\hline $\begin{array}{l}\text { Mandal and Deshmukh } \\
(1994)\end{array}$ & Vendor selection \\
\hline Sharma et al. (1995) & Waste management \\
\hline $\begin{array}{l}\text { Singh } \text { et al. } \text { (2003), Singh and } \\
\text { Kant (2008) }\end{array}$ & Knowledge management \\
\hline
\end{tabular}




\begin{tabular}{|c|c|}
\hline $\begin{array}{l}\text { Ravi and Shankar (2005), } \\
\text { Govindan et al. (2012) }\end{array}$ & Reverse logistics \\
\hline Bolanos et al. (2005) & Decision making in different functional areas \\
\hline Agarwal et al. (2006) & Agility in Automobile supply chain \\
\hline Thakkar et al. (2006) & Develop balanced scorecard for performance measurement \\
\hline Thakkar et al. (2007) & Evaluate buyer-supplier relationship \\
\hline Sagheer et al. (2009) & Identify critical factors in food industry \\
\hline Sharma and Garg (2010) & Performance evaluation of automobile service center \\
\hline Manoharan et al. (2010) & Design and plan training program \\
\hline Talib et al. 2011 & Total quality management \\
\hline Lin et al. (2011) & Vendor performance evaluation \\
\hline Poloi et al. (2012) & Agility in construction industry \\
\hline Mitra and Shankar (2012) & Technical education \\
\hline Chang et al. (2013) & Agile manufacturing system \\
\hline Dubey et al. (2015) & Green supply chain management \\
\hline Zhang et al. (2015) & Strategy for power system \\
\hline AlZebdeh et al. (2015) & Evaluate cost overrun in construction project \\
\hline $\mathrm{Wu}$ et al. (2015) & Risk assessment \\
\hline Hussain et al. (2016) & Sustainable supply chain management \\
\hline
\end{tabular}

Table 4: Structured self-interaction matrix (SSIM)

\begin{tabular}{|c|c|c|c|c|c|c|c|c|c|c|c|c|}
\hline $\begin{array}{c}\text { Factors } \\
(i / j)\end{array}$ & 12 & 11 & 10 & 9 & 8 & 7 & 6 & 5 & 4 & 3 & 2 & 1 \\
\hline 1 & $O$ & $O$ & $O$ & $V$ & $V$ & $O$ & $O$ & $V$ & $V$ & $O$ & $X$ & \\
\hline 2 & $V$ & $V$ & $V$ & $V$ & $V$ & $V$ & $V$ & $V$ & $V$ & $V$ & & \\
\hline 3 & $V$ & $O$ & $V$ & $A$ & $O$ & $A$ & $O$ & $A$ & $V$ & & & \\
\hline 4 & $V$ & $V$ & $V$ & $A$ & $O$ & $A$ & $O$ & $A$ & & & & \\
\hline 5 & $O$ & $V$ & $V$ & $O$ & $X$ & $O$ & $O$ & & & & & \\
\hline 6 & $O$ & $O$ & $V$ & $A$ & $X$ & $O$ & & & & & & \\
\hline 7 & $V$ & $O$ & $V$ & $X$ & $V$ & & & & & & & \\
\hline 8 & $O$ & $O$ & $V$ & $A$ & & & & & & & \\
\hline 9 & $O$ & $O$ & $O$ & & & & & & & & \\
\hline 10 & $O$ & $X$ & & & & & & & & & &
\end{tabular}


Table 5: Initial reachability matrix (IRM)

\begin{tabular}{|c|c|c|c|c|c|c|c|c|c|c|c|c|}
\hline Factors $(i / j)$ & 1 & 2 & 3 & 4 & 5 & 6 & 7 & 8 & 9 & 10 & 11 & 12 \\
\hline 1 & 1 & 1 & 0 & 1 & 1 & 0 & 0 & 1 & 1 & 0 & 0 & 0 \\
\hline 2 & 1 & 1 & 1 & 1 & 1 & 1 & 1 & 1 & 1 & 1 & 1 & 1 \\
\hline 3 & 0 & 0 & 1 & 1 & 0 & 0 & 0 & 0 & 0 & 1 & 0 & 1 \\
\hline 4 & 0 & 0 & 0 & 1 & 0 & 0 & 0 & 0 & 0 & 1 & 1 & 1 \\
\hline 5 & 0 & 0 & 1 & 1 & 1 & 0 & 0 & 1 & 0 & 1 & 1 & 0 \\
\hline 6 & 0 & 0 & 0 & 0 & 0 & 1 & 0 & 0 & 0 & 1 & 0 & 0 \\
\hline 7 & 0 & 0 & 1 & 1 & 0 & 0 & 1 & 1 & 1 & 1 & 0 & 1 \\
\hline 8 & 0 & 0 & 0 & 0 & 1 & 1 & 0 & 1 & 0 & 1 & 0 & 0 \\
\hline 9 & 0 & 0 & 1 & 1 & 0 & 1 & 1 & 1 & 1 & 0 & 0 & 0 \\
\hline 10 & 0 & 0 & 0 & 0 & 0 & 0 & 0 & 0 & 0 & 1 & 1 & 0 \\
\hline 11 & 0 & 0 & 0 & 0 & 0 & 0 & 0 & 0 & 0 & 1 & 1 & 0 \\
\hline 12 & 0 & 0 & 0 & 0 & 0 & 0 & 0 & 0 & 0 & 0 & 0 & 1 \\
\hline
\end{tabular}

Table 6: Final reachability matrix

\begin{tabular}{|c|c|c|c|c|c|c|c|c|c|c|c|c|}
\hline Factors $(i / j)$ & 1 & 2 & 3 & 4 & 5 & 6 & 7 & 8 & 9 & 10 & 11 & 12 \\
\hline 1 & 1 & 1 & 0 & 1 & 1 & $1^{*}$ & 0 & 1 & 1 & $1^{*}$ & 0 & $1^{*}$ \\
\hline 2 & 1 & 1 & 1 & 1 & 1 & 1 & 1 & 1 & 1 & 1 & 1 & 1 \\
\hline 3 & 0 & 0 & 1 & 1 & 0 & 0 & 0 & 0 & 0 & 1 & $1^{*}$ & 1 \\
\hline 4 & 0 & 0 & $1^{*}$ & 1 & 0 & 0 & 0 & 0 & 0 & 1 & 1 & 1 \\
\hline 5 & 0 & 0 & 1 & 1 & 1 & 0 & 0 & 1 & 0 & 1 & 1 & 0 \\
\hline 6 & 0 & 0 & 0 & 0 & 0 & 1 & 0 & 0 & 0 & 1 & 0 & 0 \\
\hline 7 & 0 & 0 & 1 & 1 & 0 & 0 & 1 & 1 & 1 & 1 & 0 & 1 \\
\hline 8 & 0 & 0 & 0 & 0 & 1 & 1 & 0 & 1 & 0 & 1 & $1^{*}$ & 0 \\
\hline 9 & 0 & 0 & 1 & 1 & 0 & 1 & 1 & 1 & 1 & 0 & 0 & 0 \\
\hline 10 & 0 & 0 & 0 & 0 & 0 & 0 & 0 & 0 & 0 & 1 & 1 & 0 \\
\hline 11 & 0 & 0 & 0 & 0 & 0 & 0 & 0 & 0 & 0 & 1 & 1 & 0 \\
\hline 12 & 0 & 0 & 0 & 0 & 0 & 0 & 0 & 0 & 0 & 0 & 0 & 1 \\
\hline
\end{tabular}

Table 7: Levels of factors that affect agility in O\&G industry

\begin{tabular}{|c|l|l|l|l|}
\hline Factors $i$ & \multicolumn{1}{|c|}{ Reachability set } & \multicolumn{1}{|c|}{ Antecedent set } & Intersection set & \multicolumn{1}{c|}{ Level } \\
\hline 1 & $1,2,4,5,6,8,9,10,12$ & 1,2 & 1,2 & Level VI \\
\hline 2 & $1,2,3,4,5,6,7,8,9,10,11,12$ & 1,2 & 1,2 & Level VI \\
\hline 3 & $3,4,10,11,12$ & $2,3,4,5,7,9$ & 3,4 & Level III \\
\hline 4 & $3,4,10,11,12$ & $1,2,3,4,5,7,9$ & 3,4 & Level III \\
\hline 5 & $3,4,5,8,10,11$ & $1,2,5,8$ & 5,8 & Level IV \\
\hline 6 & 6,10 & $1,2,6,8,9$ & 6 & Level III \\
\hline 7 & $3,4,7,8,9,10,12$ & $2,7,9$ & 7,9 & Level V \\
\hline
\end{tabular}




\begin{tabular}{|l|l|l|l|l|}
\hline 8 & $5,6,8,10,11$ & $1,2,5,7,8,9$ & 5,8 & Level IV \\
\hline 9 & $3,4,6,7,8,9$ & $1,2,7,9$ & 7,9 & Level V \\
\hline 10 & 10,11 & $1,2,3,4,5,6,7,8,10,11$ & 10,11 & Level II \\
\hline 11 & 10,11 & $2,3,4,5,8,10,11$ & 10,11 & Level II \\
\hline 12 & 12 & $1,2,3,4,7,12$ & 12 & Level I \\
\hline
\end{tabular}

Table 8: Conical matrix with factor ranking

\begin{tabular}{|c|c|c|c|c|c|c|c|c|c|c|c|c|c|c|}
\hline Factors $(i / j)$ & 12 & 10 & 11 & 3 & 4 & 6 & 5 & 8 & 7 & 9 & 1 & 2 & $\begin{array}{c}\text { Driving } \\
\text { power }\end{array}$ & Ranking \\
\hline 12 & 1 & 0 & 0 & 0 & 0 & 0 & 0 & 0 & 0 & 0 & 0 & 0 & 1 & $7^{\text {th }}$ \\
\hline 10 & 0 & 1 & 1 & 0 & 0 & 0 & 0 & 0 & 0 & 0 & 0 & 0 & 2 & $6^{\text {th }}$ \\
\hline 11 & 0 & 1 & 1 & 0 & 0 & 0 & 0 & 0 & 0 & 0 & 0 & 0 & 2 & $6^{\text {th }}$ \\
\hline 3 & 1 & 1 & $1 *$ & 1 & 1 & 0 & 0 & 0 & 0 & 0 & 0 & 0 & 5 & $5^{\text {th }}$ \\
\hline 4 & 1 & 1 & 1 & $1 *$ & 1 & 0 & 0 & 0 & 0 & 0 & 0 & 0 & 5 & $5^{\text {th }}$ \\
\hline 6 & 0 & 1 & 0 & 0 & 0 & 1 & 0 & 0 & 0 & 0 & 0 & 0 & 2 & $6^{\text {th }}$ \\
\hline 5 & 0 & 1 & 1 & 1 & 1 & 0 & 1 & 1 & 0 & 0 & 0 & 0 & 6 & $4^{\text {th }}$ \\
\hline 8 & 0 & 1 & $1 *$ & 0 & 0 & 1 & 1 & 1 & 0 & 0 & 0 & 0 & 5 & $5^{\text {th }}$ \\
\hline 7 & 1 & 1 & 0 & 1 & 1 & 0 & 0 & 1 & 1 & 1 & 0 & 0 & 7 & $3^{\text {rd }}$ \\
\hline 9 & 0 & 0 & 0 & 1 & 1 & 1 & 0 & 1 & 1 & 1 & 0 & 0 & 6 & $4^{\text {th }}$ \\
\hline 1 & $1 *$ & $1 *$ & 0 & 0 & 1 & $1^{*}$ & 1 & 1 & 0 & $1 *$ & 1 & 1 & 9 & $2^{\text {nd }}$ \\
\hline 2 & 1 & 1 & 1 & 1 & 1 & 1 & 1 & 1 & 1 & 1 & 1 & 1 & 12 & $1^{\text {st }}$ \\
\hline Dependence & 5 & 10 & 7 & 6 & 7 & 6 & 4 & 6 & 3 & 4 & 2 & 2 & & \\
\hline Ranking & $3^{\text {rd }}$ & $1^{\text {st }}$ & $2^{\text {nd }}$ & $3^{\text {rd }}$ & $2^{\text {nd }}$ & $4^{\text {th }}$ & $5^{\text {th }}$ & $3^{\text {rd }}$ & $6^{\text {th }}$ & $5^{\text {th }}$ & $7^{\text {th }}$ & $7^{\text {th }}$ & & \\
\hline
\end{tabular}




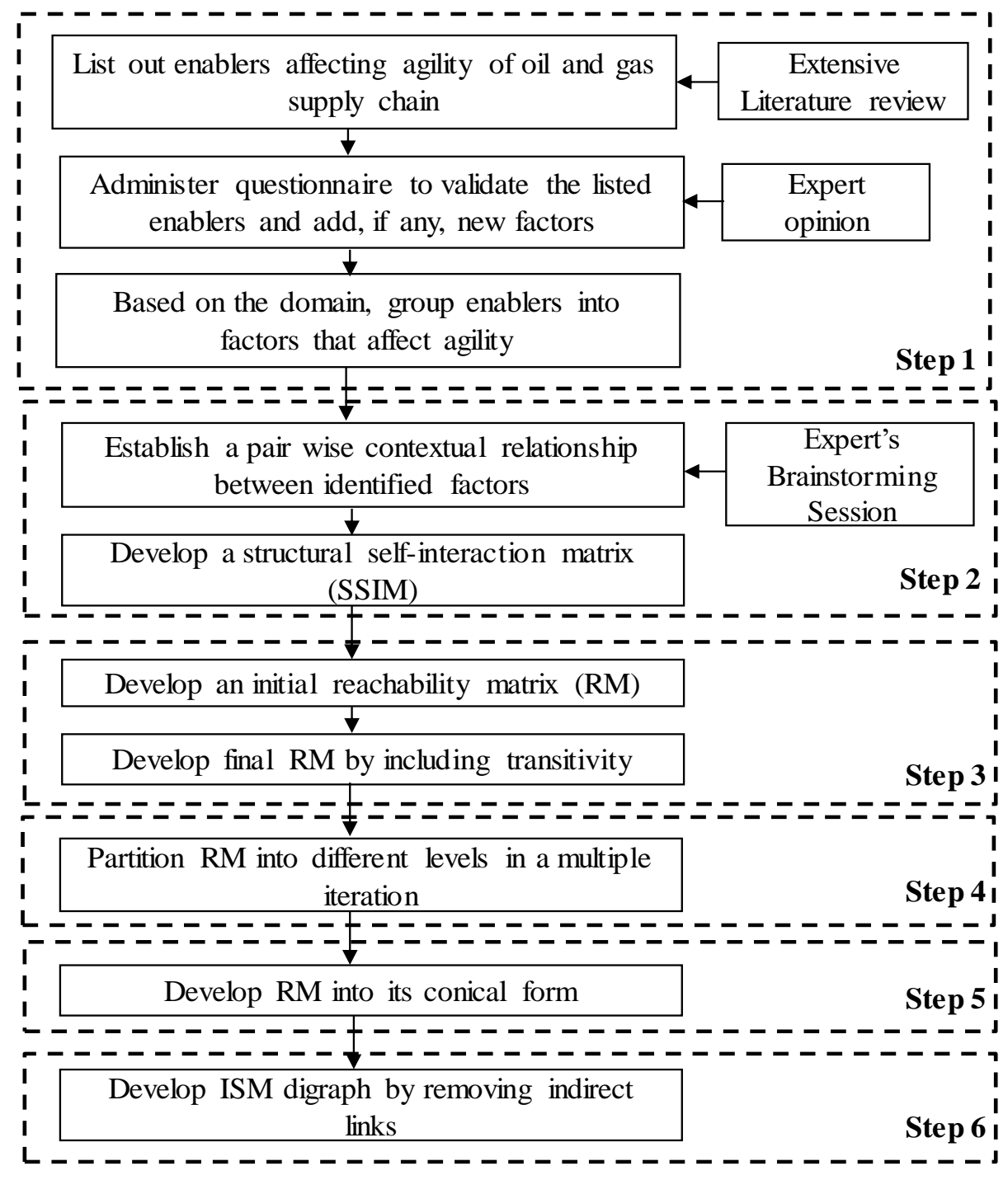

Figure 1: Steps in using ISM 


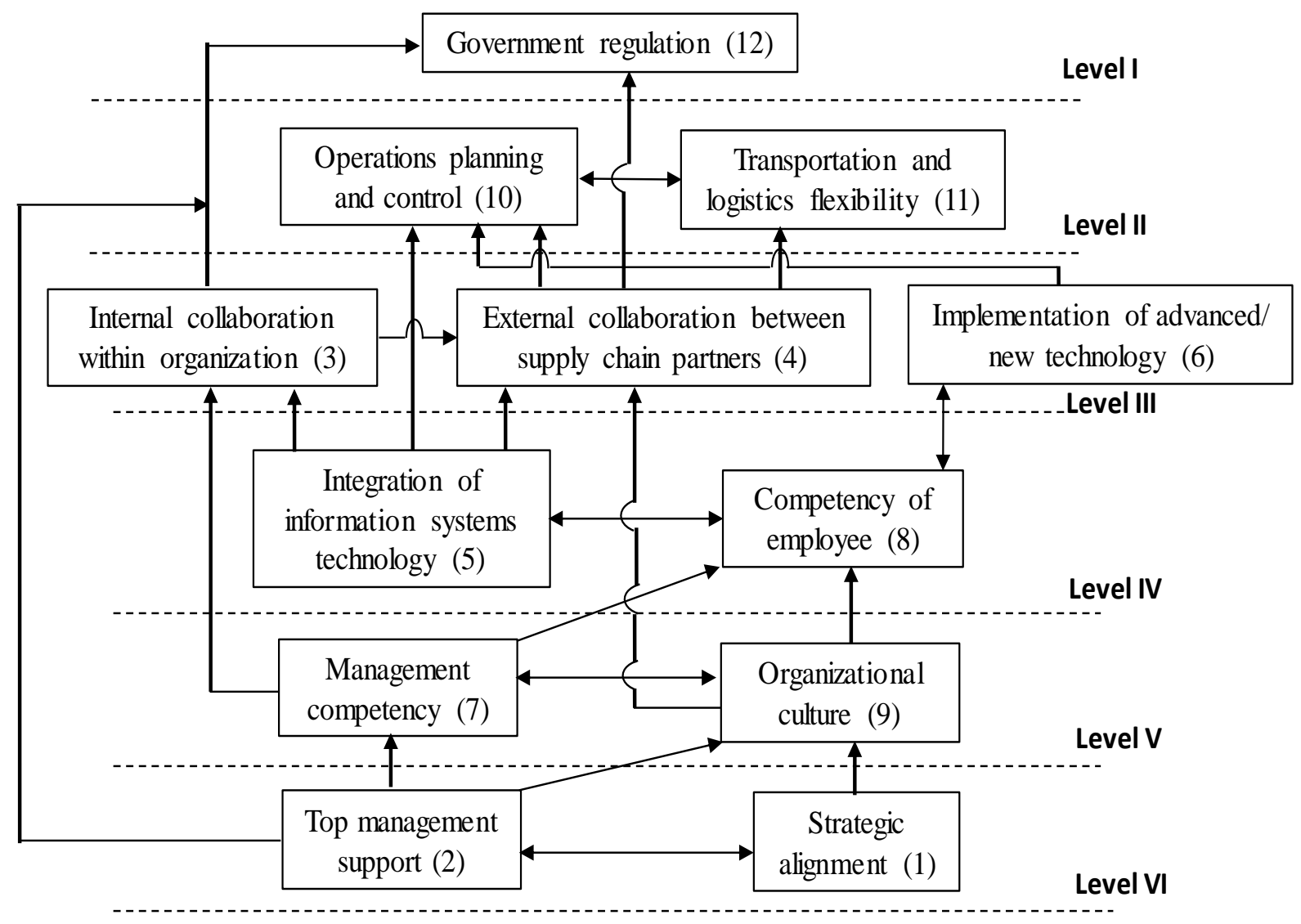

Figure 2: ISM diagraph for supply chain agility

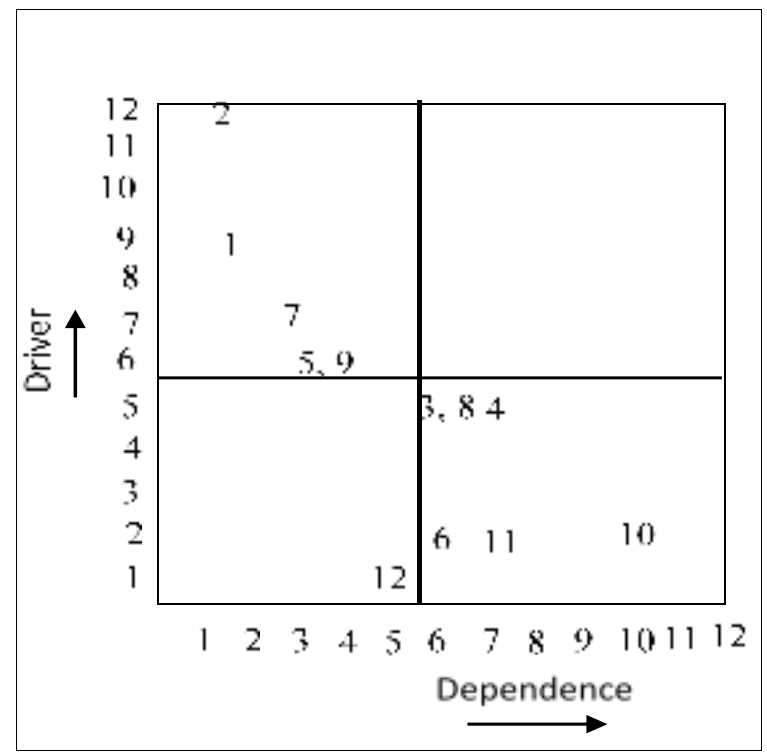

Figure 3: MICMAC analysis 